\title{
New and Forthcoming
}

\section{By Dr. Lori Mestre}

Armstrong, Steven J. and Cynthia V. Fukami. The SAGE Handbook of Management Learning, Education and Development. London: Sage Publications, Ltd. 2009. ISBN: 978-1-4129-3539-5. OCLC: 214308676. $\$ 140.00 .600$ pp.

This Handbook is the first to provide an account of the scholarship of management teaching and learning. Chapters, written by leading academics, provide a comprehensive and critical overview of the given topic area, highlights current debate, and reviews the emerging research agenda. Organized in three parts, the chapters discuss aspects of the study of organizations, concepts of individual and collective learning, delivery of formal management education and facilitation of management development.

Intended for students and researchers interested in broadening their understanding of this new field.

Ayers, William, Therese Quinn, and David Stovall (Eds.). Handbook of Social Justice in Education. London: Routledge, 2008. ISBN: 0-8058-5927-6; ISBN13: 978-0-8058-5927-0. OCLC: 190396172. $\$ 225.00 .792$ pp.

The Handbook of Social Justice Education provides a review of education theory, research, and practice in historical and ideological context, with an emphasis on social movements for justice in the area of social justice education. Themes are arranged in nine sections: Historical and Theoretical Perspectives; International Perspectives on Social Justice in Education; Race and Ethnicity, Language and Identity: Seeking Social Justice in Education; Gender, Sexuality and Social Justice in Education; Bodies, Disability and the Fight for Social Justice in Education; Youth and Social Justice in Education; Globalization: Local and World Issues in Education; The Politics of Social Justice Meets Practice: Teacher Education and School Change; and Classrooms, Pedagogy, and Practicing Justice. Intended for researchers, professionals, and students across the fields of educational foundations, multicultural/diversity education, educational policy, and curriculum and instruction. Illustrated.

Charner, Kathy, Maureen Murphy and Charlie Clark (Eds). The GIANT Encyclopedia of Lesson
Plans: For Children 3-6: More Than 250 Lesson Plans Created by Teachers for Teachers. Beltsville, MD: Gryphon House, 2008. ISBN: 0-87659-068-7; ISBN13: 978-0-87659-068-3. OCLC: 213384895. GIANT Encyclopedia Ser. Illustrated. \$34.95. 544 pp.

This newest edition includes more than 250 lesson plans written by teachers for teachers. Topics range from colors and numbers to seasons and nursery rhymes. Each lesson plan is complete with: a learning objective; a circle or group time activity book; suggestions; snack ideas; five learning center activities; and assessment strategies. Also included are related songs, poems, and fingerplays. Includes indexes.

\section{English, Fenwick W. Educational Leadership and} Administration. 4 vols. London: SAGE Publications Ltd, 2009. ISBN: 978-1-8478-7564-8. OCLC: 228362900. Series: Sage Library of Educational Thought \& Practice. \$1,050.00. 1768 pp.

The articles and chapters in Educational Leadership and Administration draw on the broad perspectives of experts in the areas of behaviorism, structuralism, critical theory, and postmodernism from the United States, Canada, the United Kingdom, Hong Kong, Australia, and New Zealand. It provides a global perspective of the leading theories, turning points and ideas within educational leadership and administration within the last 30-40 years. Intended as a reference resource for any student in the field.

\section{Henderson, Patricia. The New Handbook of Administrative Supervision in Counseling. New York: Routledge, 2009. ISBN: 0-415-99584-1; ISBN13: 978- 0-415-99584-9. OCLC: 231582492. \$69.95. 368 pp.}

This resource is written for first line supervisors who work in mental health agencies, private practices, or in schools. Nineteen chapters are grouped into six sections the highlight the skills needed to fulfill eighteen job responsibilities such as implementing your vision, advocating for services and staff members, navigating the politics inherent in work environments, team building, managing budgets and other realities, while still maintaining your own professional integrity and development. Includes forms and self-directed exercises 
to facilitate personal reflection. Includes appendixes and references.

Kuper, Adam and Jessica Kuper (Eds). The Social Science Encyclopedia. $3^{\text {rd }}$ ed. London;

Boston:_Routledge, 2008. 978-0-415-47635-5. OCLC: 63046844. \$55.95, 1160 pp.

This third edition of the Social Science Encyclopedia includes major rewrites and new entries. The 500 entries, written by international contributors and experts, cover the critical areas in social sciences study and research and also review topics such as neoevolutionism, rational choice theory and poststucturalism. Recommended for all libraries.

Hornberger, Nancy H. (Ed.). Encyclopedia of Language and Education, $2^{\text {nd }}$ ed. 10 vols. New York: Springer, 2008. ISBN: 0-387-30424-X; ISBN13: 9780-387-30424-3. OCLC: 185028339. \$1,500.00.

This 10 volume revised set of the Encyclopedia of Language and Education brings forth the newest developments in the field, including two new volumes on language socialization and language ecology. The addition of these volumes reflects the growing emphases in language education theory, research and practice, alongside the emphases on language policy, literacies, discourse, language acquisition, bilingual education, knowledge about language, language testing, and research methods. More than 250 international scholars contributed to the Encyclopedia providing global perspectives on the field. Most contributors give coverage of early developments in their topic, major contributions, work in progress, problems and difficulties, and future directions. The themes of the volumes are: 1: Language Policy and Political Issues in Education; 2: Literacy 3: Discourse and Education; 4: Second and Foreign Language Education; 5: Bilingual Education; 6: Knowledge About Language; 7: Language Testing and Assessment; 8: Language Socialization; 9: Ecology of Language; 10: Research Methods in Language and Education. Includes references and indexes. Intended for college and university libraries.

Noffke, Susan E. and Bridget Somekh. The SAGE Handbook of Educational Action Research. London: SAGE Publications Lt., 2008. ISBN: 978-1-41294708-4. OCLC: 228363047. \$140.00. 568 pp.

This SAGE Handbook of Educational Action Research is organized into four sections that provide theoretical and practical based information by highly respected scholars in the area of Educational Action Research. The four sections of the handbook are: Action research methodology: diversity of rationales and practices; Professional: Knowledge production, staff development, and the status of educators; Personal: Self-awareness, development and identity; and Political: Popular knowledge, difference, and frameworks for change. An opening chapter provides the historical development of action research, along with an analysis of the theories. Other chapters exemplify the work of prominent practitioner and community groups working outside universities. Intended for scholars and graduate students at doctors and masters levels, as well as school leaders and administrators.

Reid, Gavin et al. The SAGE Handbook of Dyslexia. Los Angeles; London: Sage Publications, Ltd, 2008. ISBN: 978-1-4129-4513-4. OCLC: 228363341. $\$ 140.00 .505$ pp.

The SAGE Handbook of Dyslexia is a comprehensive overview of the field. It provides an assessment of past and present theory, as well as current research.

Researchers and practitioners examine the relationships between theoretical paradigms, research and practice, and to map new areas of research. The five parts of the book are: Neurological/Genetic Perspectives; Cognitive and Learning Perspectives; Educational Influences; Dyslexia and Different Languages; and Beyond School. Intended for postgraduates and academic researchers in special educational needs and educational psychology. Includes bibliographical references and index.

Reynolds, Cecil. R. (Ed.) Handbook of School Psychology, $4^{\text {th }}$ ed. Hoboken, NJ: John Wiley \& Sons, Incorporated, 2009. ISBN: 0-471-70747-3; ISBN13: 978-0-471-70747-9. OCLC: 228676668. 969 pp.

This edited handbook focuses on how a school psychologist can operate and create change within the educational system instead of focusing solely on the diagnosis and treatment of an individual. Chapters have been updated and revised to provide a contemporary view of the field. The 43 chapters are grouped into the four sections of: The Scientific Foundations of School Psychology; Psychological and Educational Assessment; Interventions: Focus on Children; and Interventions: Focus on Systems. Includes bibliographical references and index. 
Rudestam, Kjell Erik and Judith Scholenholz-Read. Handbook of Online Learning. $2^{\text {nd }}$ ed. Thousand Oaks, CA: Sage Publication, Inc. ISBN: 978-1-41296103-5. OCLC: 280543998. \$56.95.

The $2^{\text {nd }}$ edition of the Handbook of Online Learning includes twelve new articles central to online learning. This book provides a foundation for those working with online programs along with practical applications. Part 1 presents philosophies and theories of learning, along with the theoretical and conceptual base. Part II covers the practice of online learning, interactive teaching and pedagogical strategies. Included are chapters on online learning research, evolving technologies, course management systems, virtual libraries, teaching to be effective online facilitators, and the challenge of culture and community in online academic environments. Intended for teachers and administrators of online courses and programs.

Smith, M. Cecil, and Nancy DeFrates-Densch (Eds). Handbook of Research on Adult Learning and Development. New York: Routledge, 2009. ISBN 13: 978-0-8058-5819-8. OCLC: 190396106. \$275.00. 809 pp.

This Handbook analyzes, integrates, and summarizes theoretical advances and research findings on adult development and learning. The volume is organized around six themes: Theoretical perspectives on adult development and learning; Research methods in adult development; Research on adult development; Research on adult learning; Aging and gerontological research; and Policy perspectives on aging. Intended for researchers, faculty, graduate students and practitioners whose work pertains to adult and lifespan development and learning. Includes bibliographical references and index.
Wallace, Susan. A Dictionary of Education. London; Oxford: Oxford University Press, 2008. ISBN-13: 978-0-1992-1206-4 ISBN-10: 0-1992-1206-6. \$120.00. 432 pp.

This UK based dictionary provides concise definitions of 1,250 terms related to education, including preschool, primary, secondary, higher education and adult and continuing education. Also included are entries for major legislation, key figures and organizations and curriculum and assessment terminology. Entry level weblinks are updated through a companion website. Includes crossreferenced appendix of comparative terms in the U.S., Canada, Australia and other English-speaking countries. Includes appendixes and glossary.

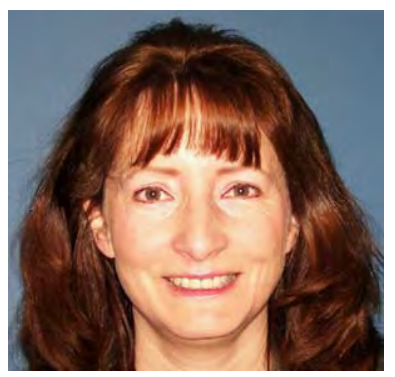

Dr. Lori Mestre is the Digital Learning Librarian at the University of Illinois at Urbana-Champaign. lmestre@uiuc.edu 